\title{
Agriculture and Development in the Wake of the Arab Spring
}

\author{
Eckart Woertz ${ }^{1}$
}

\begin{abstract}
This paper analyses the role of agriculture in the political economy of the Middle East and North Africa (MENA). It outlines agriculture's relative contribution to development and employment, shows linkages with food security policies, and discusses possible future scenarios. Agriculture's role in the economies of MENA is limited nowadays, but its contribution to employment is still substantial. In many countries it is at the heart of the region's water crisis as it withdraws about 80 per cent of water resources. Agricultural constituencies have played an important role in sociopolitical transformations of the region. Populist regimes tried to win them over-as support base-with land reforms enacted in the 1950 s and 1960s. Since the 1980 s these earlier reforms have been pushed back and the sector has been liberalised under bureaucratic-authoritarian reform coalitions. In other countries, such as Saudi Arabia, extensive production subsidies have been maintained. The MENA region is the largest cereal importer in the world and its governments regard this dependency as a strategic liability. However, the quest for self-sufficiency has proven to be elusive in the light of natural constraints and population growth. The major challenge in MENA is not macro food security or lack of calories, but deficiencies of micronutrients such as vitamins and iron and a lack of accessible food for the poor. Hence, inclusive growth, rural livelihood strategies, and political participation will be crucial for food security in MENA.
\end{abstract}

\section{Introduction}

Worldwide, agriculture has seen a relentless decline in its gross domestic product (GDP) contribution and employment capacities compared to industry and services. The Middle East and North Africa (MENA) is no exception. Agriculture's share of GDP hovers in the single digits in most countries. Its developmental and political importance is often overlooked. However, the

1 A Marie Curie Grant from the European Commission funded this research. Some parts of this article were first published in a report for the Union for the Mediterranean, Barcelona (http://ufmsecretariat.org/).

(C) ECKART WOERTZ, 2017 | DOI 10.1163/9789004336452_009

This is an open access chapter distributed under the terms of the CC-BY-NC License.kart Woertz - 9789004336452 
figures for its contribution to employment are higher and it withdraws the vast majority—around 80 per cent—of scarce water resources. Agricultural constituencies have played an important role in sociopolitical transformations of the region. Populist regimes tried to win them over-as a support base-with land reforms that enacted in the 1950s and 196os. Since the 1980s these earlier reforms have been pushed back and the sector has been liberalised under bureaucratic-authoritarian reform coalitions. In other countries, such as Saudi Arabia extensive production subsidies have been maintained.

The region is the largest food importer in the world, and its governments are keenly aware of the geopolitical vulnerability that comes with such dependence. Maintenance of domestic subsidy regimes is crucial for legitimacy, but difficult in light of fiscal constraints and structurally higher food prices on international markets since the global food crisis of 2008. Economic development, or lack thereof, was a contributing factor to the Arab-Spring uprising, and it is crucial for democratic transitions (e.g. Tunisia) and autocratic perseverance (e.g. the Gulf States or Egypt) alike.

Against this backdrop, this paper analyses the role of agriculture in the political economy of the region and its relative contribution to development and employment. It then shows linkages with general food security policies and discusses possible future developments.

Agriculture is MENA's largest water consumer and still provides a substantial proportion of employment in some of the region's countries. Its contribution to economic prosperity is much smaller. In most countries agriculture's value added as percentage of GDP is in single digit territory. In Libya, the Gulf countries and Israel it is at 2 per cent or below. In some countries, such as Egypt, Iran, Syria and Morocco, the rural population is a relatively large proportion of the total, at $31-56$ per cent; but even in these countries agriculture's contribution to employment and value added is limited, as Table 8.1 shows. In Sudan and Yemen, where a majority of the population still live in rural areas, agriculture's contribution to employment and value added also trails behind. This points to low productivity and hidden unemployment in the countryside. In a substantially urbanised country like Turkey, for example, 3 o per cent of the labour force still work in agriculture, but generate only 8.5 per cent of the value added.

Agriculture is by far the largest water user in the region, withdrawing roughly 80 per cent-with Syria (9o per cent) and Israel (6o per cent) as outliers. Agriculture's water use is consumptive; following evapotranspiration through the plants that are grown it cannot be recycled like residential water supplies 
TABLE 8.1 Share of agriculture (\%)—rural population, labour force, value added

\begin{tabular}{|c|c|c|c|}
\hline & $\begin{array}{l}\text { Rural population } \\
\text { (\% of total } \\
\text { population) } 2013\end{array}$ & $\begin{array}{l}\text { Labour force in } \\
\text { agriculture (\% of total } \\
\text { labour force) } 2013\end{array}$ & $\begin{array}{l}\text { Agriculture, } \\
\text { value added } \\
\text { (\% of GDP) }\end{array}$ \\
\hline Morocco & 42.24 & 23.47 & $14.6(2012)$ \\
\hline Algeria & $25 \cdot 3^{2}$ & 20.09 & $9 \cdot 3(2012)$ \\
\hline Tunisia & 33.27 & 19.59 & $8.7(2013)$ \\
\hline Libya & 21.94 & 2.53 & $1.9(2008)$ \\
\hline Egypt & 56.19 & 23.22 & $14.5(2013)$ \\
\hline Israel & $7 \cdot 99$ & 1.53 & $1.6(2013)$ \\
\hline $\begin{array}{l}\text { West Bank and } \\
\text { Gaza }\end{array}$ & 25.22 & 7.06 & $6.9(2011)$ \\
\hline Jordan & 16.79 & 5.60 & $3.4(2013)$ \\
\hline Syria & 43.15 & 18.74 & $17.9(2007)$ \\
\hline Lebanon & 12.53 & 1.47 & $7.2(2013)$ \\
\hline Turkey & 26.60 & 30.40 & $8.5(2013)$ \\
\hline Kuwait & 1.72 & 1.01 & $0.5(2003)$ \\
\hline Qatar & 0.92 & 0.64 & n.a. \\
\hline Iran & 30.65 & 20.42 & $10.2(2007)$ \\
\hline Iraq & 33.61 & 4.65 & n.a. \\
\hline Bahrain & 11.19 & 0.61 & $0.9(1995)$ \\
\hline Saudi Arabia & 17.29 & 4.17 & $2.2(2012)$ \\
\hline Oman & 26.05 & $27 \cdot 5^{6}$ & $1.9(2004)$ \\
\hline UAE & 15.05 & 2.73 & $0.7(2012)$ \\
\hline Yemen & $66.5^{2}$ & $35 \cdot 74$ & $10.1(2006)$ \\
\hline South Sudan & 70.07 & 48.64 & n.a. \\
\hline Sudan & 70.07 & 48.61 & $27 \cdot 7(2012)$ \\
\hline Mauritania & $57 \cdot 99$ & 49.65 & $17.0(2012)$ \\
\hline
\end{tabular}

SOURCE: FAOSTAT, 2014; WORLD BANK, 2014; UNITED NATIONS, 2014.

or used twice like the cooling water of power plants. Hence, agriculture's share of consumptive water use is even higher, hovering around 92 per cent (Allan et al., 2015; Allan, 2011; Allan, 2001; Dawoud, 2007).

Past agricultural expansion has been ecologically and economically questionable because of its reliance on limited water resources and costly producer subsidies. Water tables in the region have been sinking at an alarming rate. In 2008 Saudi Arabia started to phase out its subsidised wheat programme (until 
2016) as aquifers containing non-renewable fossil water have been depleted. In a next step it will need to cut back its production of alfalfa, which is used as feed for livestock and is even more water intensive than wheat. In the future, Saudi Arabia plans to direct scarce water resources to more value-added crops like fruit and vegetables grown in greenhouses. Yet a reduction in the waterhungry flood irrigation of date palms is difficult because of their importance for hobby farms and weekend retreats.

Syria is another example of agricultural expansion that has been ecologically unsustainable. Unlike many other MENA countries, Syria did not neglect agriculture in the wake of the oil boom. For strategic reasons it had a keen interest in self-sufficiency. With the help of land reform and agricultural subsidies it cultivated a political support base in the countryside (Hinnebusch, 2011). The system was geared towards large-scale flood irrigation for water-intensive crops like cotton and wheat. The irrigated area doubled between 1985 and 2000. Like in neighbouring Iraq, much of this irrigation relied on pumped groundwater, not on surface water (Voss et al., 2013). By the mid-199os Syria had become selfsufficient in wheat and barley. With a short, drought-induced interruption in 1999/200o it remained so until 2008. However, aquifers were over-pumped and agricultural production was expanded in fragile steppe ecosystems. Competing agencies of the segmented, bureaucratic Syrian state cultivated an opaque culture of secrecy around water issues and were unable to introduce more efficient water management practices (de Chatel, 2014).

Agricultural production in MENA countries cannot, then, be substantially increased due to natural constraints. At best it can be stabilised at current levels with improved water management and rain-fed farming. In some cases a greater focus on more value-added crops like fruit and vegetables is indicated; this will require different technologies, infrastructure and distribution networks. Reliance on food imports is here to stay and will likely increase with population growth and more varied diets. This raises crucial questions about the reliability of global markets in supplying such food imports. Agriculture in MENA is undergoing a process of reorientation against the backdrop of past development policies, lasting socio-economic importance, and natural constraints.

\section{$3 \quad$ Historical Evolution of Land, Food, and Agricultural Policies}

'Peasants defy categorization' is the title of an introduction by John Waterbury to a book about peasants in the Arab world (Kazemi and Waterbury, 1991). Peasants made up the majority of the MENA population until not too long ago. As recently as 1980 the share of the rural population was above $5^{\circ}$ per cent 
in many MENA countries (World Bank, 2014). MENA peasants are a heterogeneous population ranging from sharecroppers ${ }^{2}$ through mid-sized farmers to large landowners. Their participation in political unrest has often articulated itself in the form of ethnic-cum-peasant protests rather than as class-based conflict. Yet the agricultural question has loomed large in MENA history and there is no escaping that it still plays a role today.

In global, comparative terms, parts of MENA-such as Egypt and Iraqhad one of the most unequal distributions of land ownership in the first half of the twentieth century. This was the result of the region's integration into a quasi-colonial export trade of agricultural commodities, including cotton, sugar, opium and silk. In the course of time, the land tenure system witnessed a transformation from Ottoman tax farming to the establishment of private land ownership and a cadastre system (Issawi, 1995; Owen, 1993).

Absentee landlords and colonialism not only embodied inequality of land ownership, they were also an impediment to the industrialisation that could have provided alternative avenues for economic development in the absence of land reform. Only Egypt saw attempts at import-substituting industrialisation in the 1920s by the urban bourgeoisie, under the aegis of Bank Misr (Davis, 1983).

These sociopolitical conflict constellations led to revolutions and land reform in the Arab world after World War II, especially in Egypt, Syria and Iraq (Waterbury, 1983; Hinnebusch, 1989; Batatu, 1978). It was mostly an uppermiddle segment of the peasantry that benefited from such reforms, being able to increase its holdings and market access. The landless and poor peasants saw only limited gains, while the power of large landlords of the ancien régime was curtailed. Building a political support base in the countryside trumped economic motivations such as developing the agricultural sector as a source of inputs and demand for the nascent import-substituting industrialisation drive. Non-distribution of nationalised land and lack of extension services after reform proved to be an issue, particularly in Iraq.

The advent of the oil boom and related Dutch-Disease phenomena further affected the efficient management of the agricultural sector. At the same time, the capacity of cities to absorb rural migration flows proved limited. The infant industries of the import-substituting industrialisation strategies did not, in some MENA countries, grow up. They only shifted import dependency from manufactured to intermediate goods and contributed to a deterioration of the balance of payments. Informal sector employment increased as the formal sector and the bureaucratic apparatuses failed to provide enough job opportunities. New arrivals often retained their rural lifestyles as part of their livelihood strategies, exemplified by the raising of goats and poultry in backyards and

2 Tenant farmers who give a part of each crop as rent. 
on rooftops. Alaa al Aswany describes this incomplete urbanisation and the ruralisation of cities in his novel The Yacoubian Building, in which he portrays a poor rooftop community of rural migrants in Cairo who lead seemingly separated lives from the more fortunate dwellers below, while the earlier, bourgeois tenants have moved to the suburbs.

MENA countries expanded food and energy subsidies in the wake of the oil boom of the 1970s. In the case of Egypt, a particularly prominent example, the government regulated cotton, wheat, rice, sugar cane, beans and winter onions via an often paradoxical mix of production taxation and consumer subsidies. In contrast, it protected livestock production by tariffs and bureaucratic import hurdles until 1987. Only the markets for fruit and vegetables remained free of government interference. This encouraged a shift of acreage into horticulture and fodder production, including clover (birsim).

In the 1980s the Egyptian state began to dismantle these policies. Fiscal pressures were one reason for this, but the government was also alarmed about a widening food gap and declining self-sufficiency. Liberalisation policies were pushed further in the 1990s. Low oil prices and reduced opportunities for the acquisition of strategic rents after the end of the Cold War strained public finances. The overextended security states of MENA that relied on institutionalized networks of coercion on a limited economic base implemented neo-liberal reform agendas that cut government expenditure and support schemes. By 1995 only cotton and sugar cane remained under government regulation in Egypt. On the consumption side the peak for food subsidies occurred in 1980 when they covered 20 commodities and accounted for 15 per cent of government spending. By 1997 this figure had declined to 6 per cent. Subsidies now only covered four commodities: coarse 'baladi' bread, coarse 'baladi' flour, edible oil, and sugar (Richards and Waterbury, 2008; Adams Jr., 2003).

Israel and Turkey are particular cases in MENA. Both reduced consumer subsidies early on, but still retain considerable producer subsidies. Turkey used to have a far-reaching programme of agricultural producer subsidies that entailed price supports, input subsidies and marketing monopolies. These have been pushed back with policies that have favoured privatisation and the removal of trade barriers. Turkey is the seventh largest agricultural economy in the world. It is one of the few countries in MENA that is a significant agricultural exporter and it has considerable self-sufficiency in cereals. It is the world's largest producer of hazelnuts, apricots, figs, cherries, quinces, raisins and poppy seeds. It is also the second largest producer of melons, watermelons, strawberries and leeks and the third largest of lentils, apples, cucumbers, green beans, green peppers, chestnuts and pistachios (USDA, 2014C). Similarly, Morocco, Tunisia and Egypt are significant exporters of fruit and vegetables- to the European Union - while importing the majority of their staple foods (López et al., 2013). 
Reform pressures on Egypt and Syria have been particularly pronounced. Both countries have faced declining oil production and became net importers of oil and petroleum products by the first decade of the new millennium. Reform measures have deeply affected rural populations. Syria embarked on an aggressive liberalisation drive in the 1990s that aimed at cutting domestic spending and mobilising international private capital (Hinnebusch, 2012). These policies accelerated by 2000, benefits accrued to accomplices, urban clients of the business community and military-security networks, while rural areas were neglected (Haddad, 2012). Small-scale farmers suffered from the withdrawal of agricultural support schemes, and — as a result - were highly vulnerable to the epic drought that wreaked havoc in Syria between 2006 and 2010. The resulting food insecurity and migration movements to cities in the west of Syria caused severe stress to the socio-economic fabric. The Syrian uprising of 2011 has been blamed on climate change in crude Malthusian terms; yet, for a fuller understanding, one needs to consider that - prior to the drought - increasing social polarisation took place, and that the regime's reaction to it was inadequate (de Chatel, 2014; Woertz, 2014).

Structural adjustment policies also affected agriculture in Egypt and contributed to increased inequality. Law 96 was fully implemented in 1997 and pushed back the land reforms of the Nasser era (Bush, 2002; Bush, 2014). The Egyptian Minister of Agriculture, Yousef Wali, was a driving force for the policy of economic liberalisation under Mubarak and a large landowner himself. The process of rolling back land reform was fraught with influence trading. Wali was stripped of his official positions following corruption charges in 2004-a remarkable feat in a regime that was not known for its excellence in governance. Thus these examples from Syria and Egypt illustrate how MENA food security has been affected by social inequalities, rural neglect, and exposure to volatile global markets for food imports.

Food self-sufficiency is not food security, although the two are often wrongly equated in MENA. Hardly any country in the world is not reliant on other countries for at least some food items, while net export capacities are concentrated in a few countries (FAO, 2012; MacDonald, 2013). Such food imports can provide security, but also constitute vulnerability. Food importing countries like Singapore and Kuwait can be perfectly food secure if they have the foreign exchange to pay for food imports and world food markets are not disrupted by export restrictions or political crises. The lower the share of food imports as 
a share of total exports and net remittances, the more food secure a country is on a macro level (see Table 8.2). Yet this does not preclude the existence of food insecurity in vulnerable households on a micro level.

Food security can be measured on different levels: globally, nationally, and locally. Furthermore, different approaches to measurement exist. The categories of the Global Hunger Index ( $G H I$ ) of the International Food Policy Research Institute (IFPRI), Concern Worldwide, and Welthungerhilfe mainly indicate calorie deficiency (percentage of the undernourished among the general

TABLE 8.2 Status of food security (FS) in MENA countries

\begin{tabular}{|c|c|c|c|c|c|}
\hline & $\begin{array}{l}\text { Macro Fs: food } \\
\text { imports/(total } \\
\text { exports + net } \\
\text { remittances) }(\%)\end{array}$ & $\begin{array}{l}\text { Micro Fs: preva- } \\
\text { lence of stunted } \\
\text { children } \\
\text { (\% of total) }\end{array}$ & Overall Fs risk & $\begin{array}{l}\text { Score in global } \\
\text { food security } \\
\text { index, } 2013\end{array}$ & $\begin{array}{l}\text { Proportion of } \\
\text { undernourished/ } \\
\text { total population } \\
(\%), 2012-14\end{array}$ \\
\hline Morocco & 8.2 & 21.6 & Serious & $49 \cdot 4$ & $<5$ \\
\hline Algeria & $7 \cdot 3$ & 15.6 & Serious & $45 \cdot 2$ & $<5$ \\
\hline Tunisia & 6.5 & 9 & Moderate & $5^{8}$ & $<5$ \\
\hline Libya & $3 \cdot 4$ & 21 & Moderate & N/A & N/A \\
\hline Egypt & 8.7 & 30.7 & Serious & $5^{1.7}$ & $<5$ \\
\hline $\begin{array}{l}\text { West Bank } \\
\text { and Gaza }\end{array}$ & 31.9 & 11.8 & Serious & $\mathrm{N} / \mathrm{A}$ & $\mathrm{N} / \mathrm{A}$ \\
\hline Jordan & 13.9 & 8.3 & Serious & $5^{2.3}$ & $<5$ \\
\hline Syria & $9 \cdot 7$ & 28.6 & Serious & 36.7 & $\mathrm{~N} / \mathrm{A}$ \\
\hline Lebanon & 16.5 & 15 & Serious & $\mathrm{N} / \mathrm{A}$ & $<5$ \\
\hline Turkey & 2 & 13.9 & Moderate & 62.9 & $<5$ \\
\hline Iraq & o & $27 \cdot 5$ & Serious & $\mathrm{N} / \mathrm{A}$ & 23.5 \\
\hline Iran & 2.4 & 16.6 & Moderate & $\mathrm{N} / \mathrm{A}$ & $<5$ \\
\hline Saudi Arabia & 4 & 9.1 & Low & $65 \cdot 7$ & $<5$ \\
\hline Kuwait & 2.4 & 3.8 & Low & $\mathrm{N} / \mathrm{A}$ & $<5$ \\
\hline Bahrain & 2.9 & 9 & Low & $\mathrm{N} / \mathrm{A}$ & $\mathrm{N} / \mathrm{A}$ \\
\hline Qatar & 2 & 4 & Low & $\mathrm{N} / \mathrm{A}$ & $\mathrm{N} / \mathrm{A}$ \\
\hline UAE & 3.4 & $\mathrm{~N} / \mathrm{A}$ & Low & $\mathrm{N} / \mathrm{A}$ & $<5$ \\
\hline Oman & 6.2 & 9.6 & Low & $\mathrm{N} / \mathrm{A}$ & $\mathrm{N} / \mathrm{A}$ \\
\hline Yemen & $15 \cdot 4$ & 59.6 & Ex. Alarming & 29.6 & $25 \cdot 7$ \\
\hline Sudan & 8.4 & 37.9 & Alarming & $25 \cdot 2$ & $24.3(2009-11)$ \\
\hline Mauretania & 20.6 & 24.2 & Alarming & $\mathrm{N} / \mathrm{A}$ & 6.5 \\
\hline
\end{tabular}

SOURCE: BREISINGER ET AL., 2012; EIU, 2013; FAO ET AL., 2014. 
population, prevalence of the underweight, and mortality among children younger than five). Here the MENA region does not score badly on average, with low food security risk. Only Syria (moderate), Iraq and Mauritania (serious) and Yemen and Sudan (alarming) have more serious food security risks and issues with calorie deficiencies, according to the GHI (IFPRI et al., 2014). This is also reflected in the low proportion of undernourished people in most MENA countries as per the State of Food Insecurity report, issued by the Food and Agriculture Organization (FAO), the International Fund for Agricultural Development (IFAD), and the World Food Programme (WFP) (see Table 8.2).

Yet food security has an important micro-nutritional dimension. One can have enough calories, even too many of them, and yet be food insecure. In all, 30 per cent of the Egyptian population are obese, many of them poor, and all the while they face food insecurity due to a lack of micronutrients such as iron and vitamins. Besides poverty, uninformed dietary choices and increased consumption of junk food are contributing to a growing intake of calorie rich food. A lack of micronutrients affects pregnant women and children in particular. This can have a lasting impact. Nutritional deficiency in the womb and during the first 1,00o days after birth can lead to stunting. It can affect the cognitive abilities and educational achievements of children for the rest of their lives. When poor people cannot afford a balanced and varied diet they have to resort to basic, calorie-rich food, either permanently or as a temporary stopgap solution in the case of sudden price spikes. Hence, the cost of food price volatility and inflation are only insufficiently measured by their short-term impact on financial indicators and nutrition. By compromising the physical and mental abilities of children for life, both factors can have severe long-term developmental effects.

To address these shortcomings, the Beyond the Arab Awakening report issued by Washington-based IF PRI uses stunting (insufficient height for age) as an indicator of food insecurity on the micro level, and captures micro-nutritional shortcomings and other important development aspects such as clean drinking water and access to health care better than the $G H I$ (Breisinger et al., 2012). The findings of the report are less positive for MENA countries. While only 5 to 15 per cent of children under five in the Arab world are underweight, between 15 and 25 per cent are too short for their age (Woertz, 2013b, 17).

On a macro level many MENA countries face challenges, as they spend more than 5 per cent of their export earnings and net remittances on food imports. Only Libya, Turkey, Iran and the oil-exporting Gulf countries spend less. For Jordan and Lebanon the figure is above 10 per cent. Despite these constraints on a macro level, Jordan has managed to achieve one of the best levels of food security among MENA countries on a micro level. Libya, on the other hand, had one of the worst levels of micro-level food security even before its current internal turmoil began. And this occurred despite a very comfortable position 
on a macro level. The West Bank and Gaza face the worst food security situation on a macro level, as 31.9 per cent of their export earnings and remittances are spent on food imports; but they are relatively food secure on a micro level compared to other MENA countries.

Micro-nutritional deficiencies and high occurrences of stunting lead mainly to the classification of MENA countries' food security risk as 'serious' in the IF PR I report. Only the Gulf countries have a 'low' risk, and Turkey, Tunisia and Libya a 'moderate' one. At the other end of the spectrum the food security risk in Sudan and Mauritania is deemed 'alarming', and in Yemen even 'extremely alarming'.

Like Egypt, Syria has a very high proportion of stunted children. The IF PRI report was written before the outbreak of fully fledged civil war in the country. Even at that time, Syria's food security risk was regarded as 'serious'. By now, it has presumably moved beyond being 'serious' and might have become 'alarming' or even 'extremely alarming'. Food security has massively deteriorated and the Assad regime has used food embargoes to starve rebel-held areas into submission. This is also reflected in a relatively low ranking in the Global Food Safety Initiative (G FSI) and in Maplecroft's Food Security Risk Index, both of which comprise a broad-based average of indicators (EIU, 2013; Maplecroft, 2013). Similar food security deterioration might apply to Libya. In sum, MENA countries do relatively well in terms of calorie provision and indices that measure undernourishment. They do less well when broader issues-such as nutritional value, stability of supply, food accessibility and food safety-are taken into consideration.

\section{5}

\section{Domestic Food Prices and the Politics of Subsidies}

Global food prices are different from local food prices, which are moderated by subsidies and local costs of food processing and distribution. The latter partly depend on the quality of logistics infrastructure and on domestic fuel costs and might show different price dynamics than those of agricultural raw materials. In developed countries like the us people spend a relatively low proportion of their overall budget on food, and packaged foods constitute a large proportion of spending on food items (see Figure 8.1). Hence, inflation with regard to crops only affects a fraction of overall spending on food, and the impact on overall consumer price inflation is more limited than in developing countries where people spend a larger share of their income on food and rely less on processed and packaged foods.

People in many mena countries, including Egypt, Algeria and Morocco, spend more than a third of their disposable income on food. This is close to the figures for developing countries like Kenya, and considerably above other 


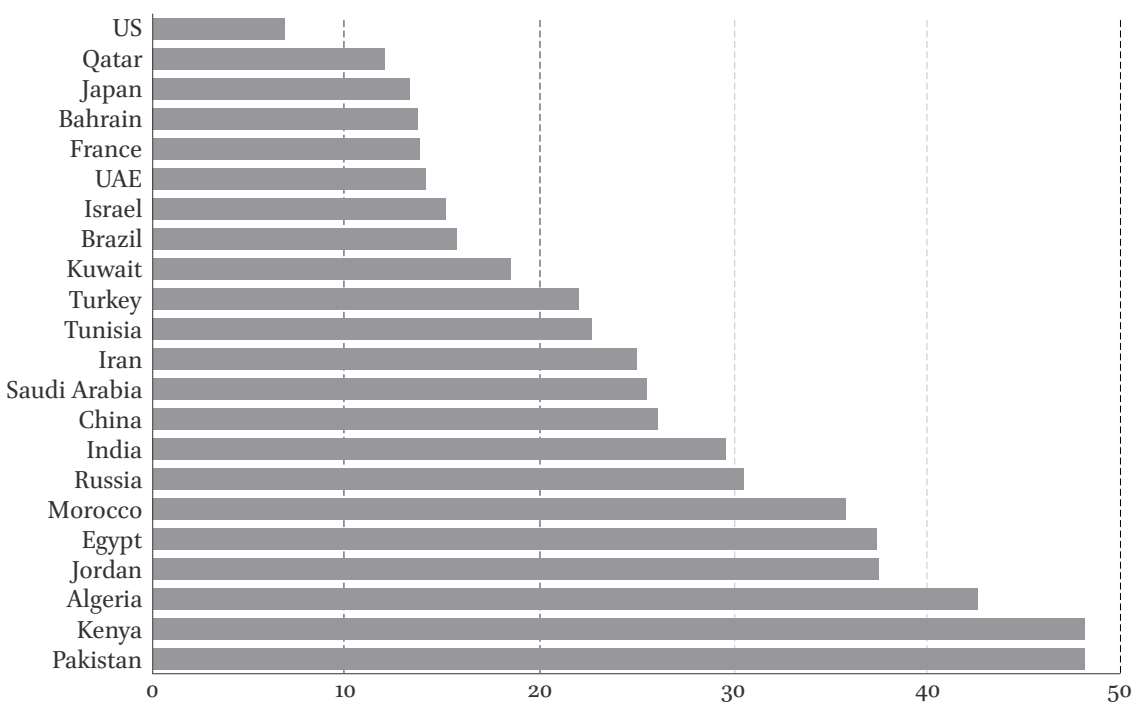

FIGURE 8.1 Percentage of income spent on food, 2013 SOURCE: USDA, 2014A.

middle-income countries such as China or Russia. Hence, these MENA countries are particularly vulnerable to food price inflation. Only the smaller Gulf countries with their higher incomes have allocation profiles that resemble those of developed countries, with food accounting for less than 20 per cent of overall household spending (see Figure 8.1).

Food, and fuel subsidies for food distribution networks, can cushion the impact of global food price shocks for local consumers and place the burden of adjustment on the shoulders of respective governments. Subsidy regimes have absorbed some of the global price hikes for consumers in MENA countries, but there has been pass-through of global food price rises by a factor of $0.2-0.4$, in line with a global average of 0.3. With the exception of the United Arab Emirates (UAE) and Yemen, food prices in MENA countries are also downwardsticky - meaning that they adjust on the way up, but do not fall back to the same extent when price corrections occur on global markets (Ianchovichina et al., 2012).

Food prices in MENA countries outpaced overall inflation rates from late 2005 to mid-2008. Overall consumer price inflation rose from 3.4 per cent in July 2007 to 10 per cent in July 2008, driven to a large extent by food price inflation, which jumped from 5.8 per cent to 14.8 per cent over this 12-month period (Albers and Peeters, 2011, 10). It has been argued that such food price rises were a contributing factor to the Arab-Spring protests. Jane Harrigan points out that 
this impact did not occur as a quasi-mechanical transmission, but should be seen in the broader context of socio-economic deterioration and a lack of political freedoms, both of which were in place prior to the protests. The impact was also uneven: while there was a significant correlation between food prices and unrest in the poorer MENA states, this was not the case in the oil-rich Gulf monarchies, and food prices did not play a role in the Libyan protest that led to the fall of the Gaddafi regime (Harrigan, 2014b). Domestic price increases in MENA have been considerably below international averages. Rather than causing outright depravation they led to a reorientation of household budgets towards basic food needs. Thus they compromised purchasing power for nonfood items, which contributed to widespread grievances about stagnating or declining living standards that have been associated with economic liberalisation, corruption, and inequalities of wealth and opportunities (Cammett et al., 2015; Verme et al., 2014).

Food and fuel subsidies in MENA countries as a proportion of GDP vary, especially in the case of fuels. In 2008 at the time of the global food crisis, they stood at around 2 per cent for food in many MENA countries and-for fuel-reached more than 6 and 12 per cent, respectively, in Egypt and Syria. Fuel subsidies have usually been considerably higher than food subsides: only Tunisia and Jordan spend more on food subsidies (Albers and Peeters, 2011). These expenditures on subsidies have been a substantial fiscal burden. In the cases of Morocco and Egypt, that burden accounted for 20 and 31 per cent, respectively, of total budgetary expenditure. This has raised questions about the sustainability of such spending. International organisations such as the World Bank and the International Monetary Fund (IMF) have called for indiscriminate food and energy subsidies to be replaced with targeted aid for the poor.

General subsidies applied to basic food items are self-targeting, as poor people spend a larger share of their disposable income on these items. They are less distorting than subsidies on energy, which disproportionately benefit the middle and upper classes with their higher ownership ratios of cars and energy-using appliances (air conditioning, washing machines, etc.). For this reason, and because they are much higher, energy subsidies are more likely candidates for further subsidy reforms than are food subsidies. Kuwait and Egypt both cut fuel subsidies in 2014, but maintained food subsidies, although Egypt introduced a smart-card system to better target bread subsidies. Food subsidies have great significance with regard to political legitimacy. This could be seen during the Arab Spring when Egyptian protesters strapped loaves of bread to their heads. It is unthinkable that they would have done the same with gallons of gasoline. Food clearly commands a greater emotional appeal andbecause of their self-targeting nature- the abolition of subsidies on staple 
foods would disproportionately hurt the poor. Moving to targeted financial aid is easier said than done, as it requires considerable monitoring capacity. Financial aid can also be subject to considerable erosion via inflation, as the recent experience of Iran with subsidy reform has shown (the Guardian, 2014).

6

\section{Macro Food Security, Import Dependence and Self-sufficiency Agendas}

Even if food security in MENA countries should not be confused with selfsufficiency and depends to a large extent on broader economic development and food imports, it does not mean that domestic agriculture does not play a role. It provides for a significant proportion of food consumption and helps create livelihoods for a still substantial part of the population, even though its contribution to value added in GDP terms lags behind and the water consumption it requires is unsustainable in many cases (Babar and Mirgani, 2014).

Table 8.3 shows how much of their own food Arab countries produce on average. Import dependence is most pronounced for cereals, sugar, and fats and oils, which are strategically crucial. Dairy products are also imported to a large degree, while meat, fish and eggs show higher self-sufficiency ratios. Some countries, such as Syria, Lebanon, Egypt, Morocco and Tunisia, even have export capacities for fruit and vegetables. Self-sufficiency ratios are lowest in the Gulf countries, Libya, Jordan, Lebanon, and the West Bank and Gaza.

Low self-sufficiency ratios are a concern in MENA countries, as they are a strategic vulnerability in times of geopolitical crisis. In the past, food imports have been threatened. During World War I a naval blockade of the Ottoman Empire by the Entente Forces caused starvation in Greater Syria, although MENA as a whole had been self-sufficient before the war. During World War II food imports were disrupted because of combat operations and lower shipping capacities; famines in the region were only averted by domestic production and the rationing and distribution system of the Allied Middle East Supply Center (MESC) in Cairo. More recently the us contemplated food embargoes in the 1970 s in retaliation for the Arab oil boycott and the Iranian hostage crisis. In the 1990s Iraq saw its food imports and oil exports cut off by a unilateral UN embargo (Woertz, 2013b).

Apart from clientelism and the politics of rent distribution, strategic concerns about macro food security have motivated programmes that have sought to increase domestic self-sufficiency, for example in Syria in the 199os and Saudi Arabia in the 1970s and 1980s. Even Jordan, with its limited natural assets and low self-sufficiency ratio, maintains production incentives for cereals (Harrigan, 2014a). Egypt increased its self-sufficiency ratio with regards to wheat from 
TABLE 8.3 Self-sufficiency ratios (\% of consumption) in Arab countries by food product category, 2011

\begin{tabular}{lrrrrrr}
\hline & $\begin{array}{l}\text { Arab region Egypt } \\
\text { average }\end{array}$ & & Jordan & $\begin{array}{l}\text { West Bank } \\
\text { and Gaza }\end{array}$ & Syria & Lebanon \\
& & & & & \\
\hline Cereals, total & 51 & 57 & 4 & 10 & 58 & 11 \\
Wheat and flour & 50 & 47 & 2 & 11 & 78 & 17 \\
Corn & 38 & 46 & 3 & 25 & 14 & 2 \\
Rice & 66 & 99 & 0 & 0 & 0 & 0 \\
Barley & 34 & 91 & 6 & 7 & 86 & 22 \\
Potatoes & 100 & 113 & 81 & 100 & 110 & 107 \\
Pulses & 60 & 43 & 7 & 8 & 111 & 25 \\
Vegetables & 102 & 105 & 177 & 126 & 158 & 91 \\
Fruit & 97 & 112 & 78 & 115 & 109 & 150 \\
Sugar & 30 & 70 & 0 & 0 & 10 & 2 \\
Fats and oils & 32 & 24 & 21 & 87 & 56 & 18 \\
Meat, total & 81 & 87 & 70 & 78 & 99 & 84 \\
Red meat & 87 & 79 & 30 & 71 & 96 & 47 \\
Poultry & 73 & 96 & 85 & 82 & 105 & 99 \\
Fish & 103 & 104 & 3 & 30 & 20 & 24 \\
Eggs & 93 & 101 & 107 & 92 & 128 & 107 \\
Milk and dairy & 71 & 84 & 46 & 94 & 107 & 33 \\
products & & & & & & \\
& & & & & & \\
\hline
\end{tabular}

SOURCE: AOAD, 2012.

21 per cent in 1986 to 46 per cent in 1998, mainly by abandoning wheat taxation and introducing improved seed varieties (Kherallah et al., 2003). By 2011, selfsufficiency had reached 60 per cent and Egypt announced a plan to reach complete self-sufficiency. Yet this aim has not yielded tangible results thus far and may prove impossible given resource constraints. Growing reliance on food imports is not going away. As it cannot be avoided it has to be managed.

\section{$7 \quad$ World Market Dependence and Trade-based Food Security}

Given population growth, limited agricultural potential and changing diets, MENA economies will continue to rely heavily on food imports. Sourcing these imports has become more expensive since the food price spikes of 2007/08 
and 2011. There have been subsequent corrections, but-overall—food prices are currently at structurally higher levels than their long-term averages of the preceding two decades. Various supply- and demand-side factors support these more elevated price levels, among them slowing productivity growth, environmental backlash and climate change on the supply side, and population growth, changing diets in emerging markets, and biofuels on the demand side (OECD-FAO, 2014).

Wheat and rice account for about 40 per cent of caloric intake globally and MENA is the largest importer of cereals in the world. At 92 million tons, its net imports are higher than the 66 million tons of East Asia, which has a much larger population. The most important net exporter countries for such food trade are North America and the former Soviet Union states, followed by Oceania/ Australia, Europe, South Asia, and South America (see Figure 8.2).

Net food imports constitute more than half the caloric intake in Arab countries; only in Syria was the share lower (before full-blown eruption of civil war) (FAO, 2012). A few strategically important net exporters satisfy this demandnamely Canada, the USA, Brazil, Argentina, France, Ukraine, Kazakhstan, Russia, Thailand, Vietnam, Australia and New Zealand. Over the last decade 70 per cent of global cereal exports were provided by only eight countries that comprised a mere 11 per cent of the global population. This global food trade is expected to rise in many countries - among them, the MENA countries - until 2050, given prevalent trends of population growth, demand patterns, and agricultural productivity and production (MacDonald, 2013).

All this food trade constitutes 'virtual water' that can be imported by MENA countries (Allan, 2001; Allan, 2011). The term virtual water describes the water that is needed to produce a particular commodity. Agriculture is by far the largest 'blue water' consumer worldwide. Globally it accounts for 70 per cent of blue water withdrawal; in MENA countries the figure is even higher, around

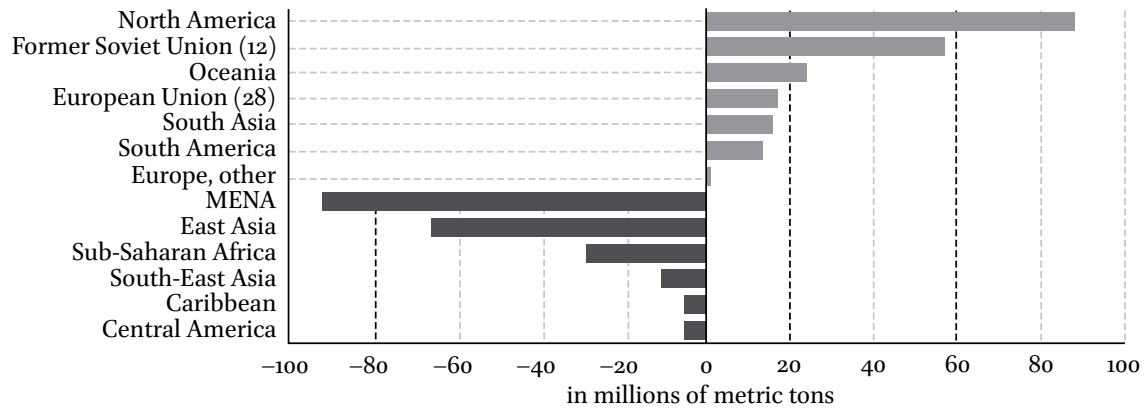

FIGURE 8.2 Global net trade in cereals 2013-2014 (millions of metric tons) SOURCE: USDA, 2014B. 
80 per cent. As water used in agriculture evaporates and cannot be reused or recycled, the sector's global share of blue water use even reaches 92 per cent if consumptive water use is considered (Allan et al., 2015). More important still, around 70 per cent of global crops are not produced by irrigation agriculture that uses blue water, but by rain-fed agriculture. The latter uses 'green water' that is contained in the soil. Such green or soil water cannot be metered, bottled or shipped by pipeline. Thus it does not figure in the global statistics regarding total renewable water reserves, which only comprise surface and groundwater. Yet green water is extremely important for global food security and for the import needs of MENA countries. By importing rain-fed cereals from Brazil, Canada or Australia, MENA countries are effectively importing the rainfalls of these locations, and can benefit from them.

Between 70 and 90 per cent of the global trade in staple food commodities is carried out by just a few food-trading houses; mainly the 'ABCDs': Archer Daniels Midland (ADM), Bunge, Cargill, and Dreyfus, plus Glencore as a fifth company (Sojamo et al., 2012). The trade in crops and derived products constitutes 76 per cent of global virtual water trade and 68 per cent of this figure comes from green water. Blue and 'grey' (waste) water contribute only 13 per cent and 19 per cent, respectively (Mekonnen and Hoekstra, 2011, 20). Currently global virtual water net exports are focussed on North America (40 per cent), Australia and New Zealand (40 per cent) and South America (20 per cent). Given available water reserves, Australia's share will likely decrease while that of Brazil is expected to rise (Allan, 2011).

Oil-rich Gulf countries have announced land investments abroad in the wake of the global food crisis, often in food-insecure countries like Sudan, Ethiopia and Pakistan. Contrary to widespread media perceptions there has been a huge implementation gap and none of these investments have provided any meaningful contribution to the region's food imports thus far. Much more important is the growing interest of MENA countries in strategic storage, food trade logistics and trade initiatives. Like Asian food importers, MENA countries are poised to engage with the global food system more extensively and more proactively (Woertz, 2013a; Keulertz and Woertz, 2015b). At the same time domestic agriculture and rural constituencies continue to play an important role in political development considerations.

\section{Challenges of Agriculture, Food Security, and Development in MENA}

Arable land and water resources in particular are scarce in MENA countries and form an impediment to any expansion of agriculture. In some countries 
agricultural production has actually had to be reduced in order to ensure water security (Alterman and Dziuban, 2010). Agricultural productivity gains might be achieved in some cases, but countries like Egypt already have some of the highest wheat productivity rates in the world. In such cases there are no meaningful yield gaps to be closed (Fischer et al., 2005).

Rather than increasing agricultural production, the focus should be on more efficient water management in order to stabilise that production. Other measures that could lead to more sustainable agriculture in MENA countries include improved extension services, fighting desertification, climate change adaptation, better distribution networks and market access, waste reduction along the value chain, broader rural development programmes, and new approaches to the governance of collective range land (CIHEAM, 2008 and 2009). The EU tries to support such reforms with its European Neighbourhood Programme for Agriculture and Rural Development (ENPARD), which runs from 2014 to 2020.

Other issues include market access to the European Union and the system of EU producer subsidies that grants considerable advantages to European farmers. One goal of the Barcelona Process or 'Euro-Mediterranean Partnership' is the establishment of a Euro-Mediterranean Free Trade Area. Manufactured goods of Partnership member countries from the southern Mediterranean shore currently enjoy duty-free access to the EU and there is preferential treatment for exports of about 80 per cent of agricultural products. Yet quantitative restrictions for some items remain and EU food safety standards can be a difficult hurdle for MENA producers to negotiate. The EU has become more competitive and runs an increasing agricultural trade surplus with MENA as a whole. Its agricultural exports almost doubled between 2006 and 2011 from EUR 4.9 to EUR 9.6 billion, while its imports from MENA only increased slightly from EUR 3.1 to EUR 3.5 billion. Turkey and Morocco are the only MENA countries that run an agricultural trade surplus with the EU, but their levels have been decreasing. Further trade liberalisation would entail winners and losers on both sides. EU producers of fruit and vegetables are concerned about competition from the south; MENA producers have similar fears with regards to cereal and livestock products from the north. Compensation payments could make such changes more palatable, but family farms are likely to face pressures and MENA governments are concerned about macro food security being compromised as a result of declining domestic cereal production (López et al., 2013).

Climate change and increased climate variability will likely exacerbate existing scarcities of water. The first changes are already visible in the eastern Mediterranean, which has witnessed an increased occurrence of drought 
(NOAA, 2011; Breisinger et al., 2011). This calls for adaptation measures from MENA countries and for their increased participation in global mitigation efforts (Luomi, 2012).

MENA governments have shown an inclination to look for supply side solutions to address water scarcity. Large-scale projects like dams, desalination, inter-basin water transfers, and tapping fossil groundwater aquifers have been the most prominent of these. One reason for this approach is that the provision of water and other public services carries great weight in terms of political legitimacy in these states, especially those that are under authoritarian rule. Directly or indirectly financed by rents from resource extraction, they try to buy the consent of a general public that is excluded from political participation. Subsidies applied to water, food and energy are part and parcel of this social contract, alongside public sector jobs and health care services. In the future, MENA governments will need to modify their focus on technical fixes and supply-side solutions and address the demand-side issues of wasteful consumption, which is encouraged by untargeted subsidies. Such an approach would require a greater integration of civil society into the processes of political decision-making (Sowers et al., 2011).

While attention of politicians and experts has focused on blue water and improved irrigation efficiency, dry land farming has been neglected. Yet blue water resources are over-utilised in MENA, whereas green water resources and dry land farming offer considerable potential to improve productivity and livelihoods (Chatterton and Chatterton, 1996; Doukkali and Lejars, 2015).

The water-energy-food nexus is eminently political and not just a technocratic construct. Concessionary finance from Gulf funds could provide an impetus, in capital-scarce MENA countries, for its improved management, particularly as climate funds, domestic capital markets, national development funds, and traditional concessionary finance from international organisations such as the World Bank are limited and entail specific trade-offs (Keulertz and Woertz, 2015a).

The political economy of food and agriculture was also highlighted by developments in the wake of the Arab Spring. Neo-liberal adjustment polices implemented by bureaucratic-authoritarian reform coalitions favoured urban clients and the economic interests of military-security networks. They disenfranchised rural constituencies and rolled back land reforms that had been enacted during the populist mobilisations of the 1950s and 196os. The resulting impoverishment and rural flight was a contributory factor to the unrest, which started in disadvantaged rural towns in the case of Tunisia and Syria and not in the major urban agglomerations. The inability of regimes to implement more efficient water management policies while cutting back support 
services for farmers also made the latter vulnerable to natural hazards such as the drought that ravaged Syria and some neighbouring countries from 2006 to 2011 (de Chatel, 2014).

The rural population and food producers who have no access to other sources of income than those generated by agriculture are often the most affected by food insecurity in MENA (Zurayk, 2011; Hamadeh et al., 2014). The economic empowerment of rural populations and their eased transition and integration into urban sectors is a major challenge. It carries implications for political stability and entails trade-offs between rural producers and urban consumers. It is unclear whether a more democratic polity in the Arab world could muster the capacity to moderate these conflicts better and implement necessary policies. Frustration with the neo-liberal clientelism of the recent past and unrealistic idealisations of the dissolved populism of yesteryear are both widespread. Meanwhile MENA seems to oscillate between unreformed authoritarian backlash and chaotic decline.

Beyond agriculture per se, inclusive economic development that keeps (imported) food affordable and accessible to MENA countries' citizens is arguably the most important long-term measure for ensuring food security. MENA countries could have fared better in this regard. With the exception of Israel and Turkey their manufacturing bases are small. Their service sectors do not have the same degree of sophistication as present in India, which is outwardoriented and geared towards provision of higher-value-added services. The tourism sectors of MENA countries have been badly hit by the ongoing wave of conflict. Innovation is hampered and barriers to entry are high. It is difficult for small and medium-sized enterprises (SMEs) to secure financing. The financial sector in MENA is dominated by bank lending ( 63 per cent), followed by stock markets (29 per cent). Bond markets are underdeveloped (7 per cent) (IMF, 2014). Bank financing leans heavily towards large companies that are owned either by influential business families or the state. sMEs that lack the necessary connections find access to funding difficult (World Bank, 2006).

Rent seeking and reliance on direct or indirect resource rents via remittances are both widespread. Military expenditure in MENA is among the highest in the world and constitutes a drain on scarce resources. In terms of GDP it stands at 4.9 per cent as compared to the global average of 2.4 per cent. It is particularly high in the Gulf States, and in Jordan, Yemen, and Syria (Harrigan, 2014b). Resource allocation has also been fraught with cronyism. Inequalities have increased globally over recent decades, harming social equitability and growth perspectives (Piketty, 2014). MENA countries are no exception to this trend. Ordinary households have hardly participated in economic development.

A focus on economic growth alone is insufficient, as the example of Egypt shows. Child malnutrition spiked in the country between 2003 and 2008, right 
at a time when GDP per capita continued to rise and the country implemented a reform agenda that was regarded favourably by international donor institutions (Breisinger et al., 2012). In 2008, in its Ease of Doing Business Index (EDBI), the World Bank referred to Egypt as the world's leading reformer. By 2010, the country had been among the top ten reformers cited in the EDBI for four years in a row (Springborg, 2012).

Yet appealing real GDP growth rates of $5^{-7}$ per cent did not trickle down to the general population. The simple averages of GDP per capita figures are misleading, as benefits only accrued to a minority. Real incomes declined for most Egyptian households throughout the first decade of the new millennium. Surprisingly, at the same time income inequality - as measured by the Gini coefficient-decreased slightly, from levels that were already relatively low compared to other developing countries with similar income per capita levels on a purchasing power basis. ${ }^{3}$ The World Bank explains this conundrum by the fact that most of the GDP growth went to private enterprises that retained or exported it; the rest of the population was worse off, despite formally decreasing income inequality (Verme et al., 2014).

It should also be kept in mind that data sources in Egypt are insufficient for reliably estimating those top incomes that have increased dramatically over the past decade. Furthermore, income inequality on a regional level is extremely high in the MENA region because of disparities between oil exporting and nonoil exporting countries (Alvaredo and Piketty, 2014). Against the backdrop of these increasing wealth inequalities and the lack of democratic institutions to address grievances, households perceived their decline in welfare terms to be even more significant than it actually already was-a combustible mix that arguably played a role in the downfall of the Mubarak regime (Harrigan, 2014b). Currently, Egypt relies on politically motivated transfer payments from the Gulf countries to pay a substantial part of its foreign bills-hardly a sustainable scenario. The elusive search for inclusive growth and the provision of social safety nets will be a crucial challenge for MENA food security.

\section{9} Conclusion

Micro-nutritional deficiencies are the most pressing food security issue in the Arab world. They are more important than the lack of self-sufficiency or lack

3 Gini coefficients in the Arab world range between 33 and 40. With 34 in 2009, Egypt was at the lower end of that range, comparable to many countries in Western Europe and below the US (40). Most countries with similar GDP per capita (PPP), such as Guatemala (57), China (47) or Georgia (39), were above that level. 
of calories, although these are often wrongly portrayed as the most salient of food security challenges. The food import dependence of MENA is here to stay and will likely grow. Inclusive economic growth is the single most important measure for safeguarding food accessibility for vulnerable people; whether that food is imported or comes from domestic production. MENA governments have fared badly in this regard during the era of economic liberalisation that began in the 1990s.

Food producers without supplementary sources of income are among the most food insecure people in MENA. In a region with already low democratic participation, their lack of access to political decision-making is pronounced. More sustainable land management policies and alternative sources of income outside agriculture would be needed to improve their livelihoods. Better extension services and distribution networks and access to credit and markets are an urgent imperative in MENA. Agricultural development will also need to move away from an overt focus on water-intensive crops like cotton and wheat towards more value-added crops like fruit and vegetables. The promulgation of water-saving technologies like drip irrigation can provide important benefits, but these technologies will not be a 'silver bullet' if efficiency gains are used to increase production and hence water consumption. Compared to irrigated agriculture, sustainable, dry-land farming has only received limited attention in MENA; but it offers considerable potential. Given the still substantial rural populations in some MENA countries and the limited absorption capacities of cities, rural livelihoods clearly have a role to play in development plans and in processes of political participation.

\section{References}

Adams R.H. Jr. (2003) 'The Political Economy and Distributional Impact of the Egyptian Food Subsidy System'. In: Lofgren, H. (ed.) Food, Agriculture, and Economic Policy in the Middle East and North Africa 1st edition ed. (Amsterdam; New York: JAI).

Albers, R. and M. Peeters (2011) Food and Energy Prices, Government Subsidies and Fiscal Balances in Southern Mediterranean Countries, Economic Papers (Brussels: European Commission, Economic and Financial Affairs Directorate-General), http:// ec.europa.eu/economy_finance/publications/economic_paper/2011/pdf/ecp437 _en.pdf (accessed on 17 March 2016).

Allan, T. (2001) The Middle East Water Question: Hydropolitics and the Global Economy (London; New York: I.B. Tauris).

Allan, T. (2011) Virtual Water: Tackling the Threat to Our Planet's Most Precious Resource (London: I.B. Tauris). 
Allan, T., M. Keulertz and E. Woertz (2015) 'The Water-Food-Energy Nexus: An Introduction to Nexus Concepts and Some Conceptual and Operational Problems', International Journal of Water Resources Development, 301-311, DOI: 10.1080/07900627.2015.1029118.

Alterman, J.B. and M. Dziuban (2010) Clear Gold. Water as a Strategic Resource in the Middle East (Washington D.C.: Center for Strategic and International Studies (CSIS)).

Alvaredo, F. and T. Piketty (2014) Measuring Top Incomes and Inequality in the Middle East: Data Limitations and Illustration with the Case of Egypt, Working Paper Series (Cairo: Economic Research Forum), http://piketty.pse.ens.fr/files/AlvaredoPiketty 2014ERF.pdf (accessed on 17 March 2016).

AOAD (Arab Organization for Agricultural Development) (2012) Arab Agricultural Statistics Yearbook (Khartoum), http://www.aoad.org/Agricultural_Statistical_Book _Vol32.pdf (accessed on 17 March 2016).

Babar, Z. and S. Mirgani (eds.) (2014) Food Security in the Middle East, (London: Hurst).

Batatu, H. (1978) The Old Social Classes and the Revolutionary Movements of Iraq: A Study of Iraq's Old Landed and Commercial Classes and of Its Communists, Ba'thists, and Free Officers, (Princeton, N.J.: Princeton University Press).

Breisinger, C., O. Ecker, P. Al-Riffai and B. Yu (2012) Beyond the Arab Awakening. Policies and Investments for Poverty Reduction and Food Security, Food Policy Report (Washington D.C.: International Food Policy Research Institute (IF PRI)).

Breisinger, C., T. Zhu, P.A. Riffai, G. Nelson, R. Robertson, J. Funes and D. Verner (2011) Global and Local Economic Impacts of Climate Change in Syria and Options for Adaptation, IF PR I Discussion Paper 01091, June (Washington D.C.: IFPRI).

Bush, R. (2002) 'Land Reform and Counter-Revolution'. In: Bush, R. (ed.) CounterRevolution in Egypt's Countryside: Land and Farmers in the Era of Economic Reform. (London, New York: Zed Books).

Bush, R. (2014) 'Food Security in Egypt'. In: Babar, Z. and Mirgani, S. (eds.) Food Security in the Middle East. (London: Hurst).

Cammett, M., I. Diwan, A. Richards and J. Waterbury (2015) A Political Economy of the Middle East, (Boulder: Westview Press).

Chatterton, L. and B. Chatterton (1996) Sustainable Dryland Farming: Combining Farmer Innovation and Medic Pasture in a Mediterranean Climate, (Cambridge England; New York, NY, usA: Cambridge University Press).

CineAm (International Centre for Advanced Agronomic Studies) (2008) Mediterra 2008: The Future of Agriculture and Food in Mediterranean Countries, (Paris).

CineAm (International Centre for Advanced Agronomic Studies) (2009) Mediterra 2009: Rethinking Rural Development in the Mediterranean, (Paris).

Davis, E. (1983) Challenging Colonialism: Bank Mișr and Egyptian Industrialization, 1920-1941, (Princeton, N.J.: Princeton University Press). 
Dawoud, M.A. (2007) Water Scarcity in the Gcc Countries: Challenges and Opportunities, Research Papers (Dubai: Gulf Research Center).

De Chatel, F. (2014). 'The Role of Drought and Climate Change in the Syrian Uprising: Untangling the Triggers of the Revolution', Middle Eastern Studies, 50, 521-535.

Doukkali, R. and C. Lejars (2015). 'Energy Cost of Irrigation Policy in Morocco: A Sam Assessment', International Journal of Water Resources Development.

EIU (The Economist Intelligence Unit) (2013) Global Food Security Index 2013 (London: EIU) http://knoema.com/GFSIEIU2013R1/global-food-security-index-2013 (accessed on 18 February 2015).

FAO (2012) Role of Imports and Net-Trade (Exports-Imports) in Total Food Consumption. Rome. http://www.fao.org/fileadmin/templates/ess/documents/food_security _statistics/Net_Trade_Calories_en.xls, (accessed 15 June 2012).

FAO, IFAD and WFP (2014) The State of Food Insecurity in the World 2014: Strengthening the Enabling Environment for Food Security and Nutrition, http://www.fao.org/3/ a-i403oe.pdf, (Rome: FAO, IFAD, WFP).

Faostat (2014) Faostat Country Profiles. Rome: Fao. (accessed 30 September 2014), http://faostat.fao.org/site/666/default.aspx (accessed on 17 March 2016).

Fischer, G., M. Shah, F. Tubiello and H. Van Velhuizen (2005). 'Socio-Economic and Climate Change Impacts on Agriculture: An Integrated Assessment, 1990-2080', Philosophical Transactions of the Royal Society B: Biological Sciences, 360, 2067-2083.

Haddad, B. (2012) Business Networks in Syria: The Political Economy of Authoritarian Resilience, (Stanford, California: Stanford University Press).

Hamadeh, S., S. Tohmé Tawk and M. Abi Said (2014) 'Urban Agriculture and Food Security in the Middle Eastern Context: A Case Study from Lebanon and Jordan'. In: Babar, Z. and Mirgani, S. (eds.) Food Security in the Middle East. (London: Hurst).

Harrigan, J. (2014a) 'An Economic Analysis of National Food Soverignty Policies in the Middle East: The Case of Lebanon and Jordan'. In: Babar, Z. and Mirgani, S. (eds.) Food Security in the Middle East. (London: Hurst).

Harrigan, J. (2014b) The Political Economy of Arab Food Sovereignty, (Basingstoke; New York: Palgrave Macmillan).

Hinnebusch, R. (1989) Peasant and Bureaucracy in Ba'thist Syria: The Political Economy of Rural Development, (Boulder: Westview Press).

Hinnebusch, R. (2011) Agriculture and Reform in Syria, (Fife, Scotland; Boulder, Co: University of St Andrews Centre for Syrian Studies; Lynne Rienner Publishers).

Hinnebusch, R. (2012). 'Syria: From “Authoritarian Upgrading” to Revolution?', International Affairs, 88, 95-113, DOI: 10.1111/j.1468-2346.2012.01059.x.

Ianchovichina, E., J. Loening and C. Wood (2012) How Vulnerable Are Arab Countries to Global Food Price Shocks?, (Washington D.C.: World Bank).

IFPRI (International Food Policy Research Institute), Concern Worldwide \& Welthungerhilfe (2014) Global Hunger Index 2014: The Challenge of Hidden Hunger (Bonn; 
Washington D.C.; Dublin), http://www.ifpri.org/sites/default/files/ghi/2014/index .html (accessed on 17 March 2016).

IMF (International Monetary Fund) (2014) Global Financial Stability Review (Washington D.C.).

Issawi, C.P. (1995) The Middle East Economy: Decline and Recovery: Selected Essays, (Princeton, N.J.: Markus Wiener Publishers).

Kazemi, F. and J. Waterbury (1991) Peasants and Politics in the Modern Middle East, (Miami Gainesville, Fla.: Florida International University Press ;Distributed by University Presses of Florida).

Keulertz, M. and E. Woertz (2015a). 'Financial Challenges of the Nexus: Pathways for Investment in Water, Energy and Agriculture in the Arab World', International Journal of Water Resources Development, 1-14, DOI: 10.1080/07900627.2015.1019043.

Keulertz, M. and E. Woertz (2015b). 'States as Actors in International Agro-Investments', International Development Policy, 6, DOI: 10.4000/poldev.2023.

Kherallah, M., N. Minot and P. Gruhn (2003) 'Adjustment of Wheat Production to Market Reform in Egypt'. In: Lofgren, H. (ed.) Food, Agriculture, and Economic Policy in the Middle East and North Africa. (Amsterdam, New York: JAI).

López, R.C., J.-M. García-Álvarez-Coque and T.G. Azcárate (2013) Eu-Mediterranean Relations in the Field of Agriculture: The Example of Morocco and Turkey, Policy Paper (Paris: Notre Europe-Jaques Delors Institute), http://www.eng.notre-europe.eu/ media/mediterraneanagriculture-lopezgarciagarcia-ne-jdi-aprı3.pdf?pdf=ok $\quad$ (accessed on 17 March 2016).

Luomi, M. (2012) The Gulf Monarchies and Climate Change: Abu Dhabi and Qatar in an Era of Natural Unsustainability, (London: Hurst \& Company).

Macdonald, G.K. (2013). 'Eating on an Interconnected Planet', Environmental Research Letters, 8, 021002.

Maplecroft(2013)Maplecroft's FoodSecurity RiskIndex 2013 (Bath, uk), http://maplecroft .com/about/news/food_security_risk_index_2013.html, (accessed on 18 February 2015).

Mekonnen, M. and A. Hoekstra (2011) National Water Footprint Accounts: The Green, Blue and Grey Water Footprint of Production and Consumption, Value of Water (Delft: UNESCO-IHE Institute of Water Education) http://www.waterfootprint .org/Reports/Report5o-NationalWaterFootprints-Vol1.pdf.(accessed on 17 March 2016).

National Oceanic and Atmospheric Administration (NOAA) (2011) NOAA Study: Human-Caused Climate Change a Major Factor in More Frequent Mediterranean Droughts (Wahsington D.C.: NOAA) http://www.noaanews.noaa.gov/stories2o11/ 20111027_drought.html (accessed 8 January 2014).

OECD-FAO (2014) Agricultural Outlook 2014-2023 (Paris: OECD Publishing) DoI: 10.1787/ agr_outlook-2014-en. 
Owen, R. (1993) The Middle East in the World Economy, 180o-1914, (London; New York: I.B. Tauris).

Piketty, T. (2014) Capital in the Twenty-First Century, (Cambridge, Mass.: Belknap Press of Harvard Univeristy Press).

Richards, A. and J. Waterbury (2008) A Political Economy of the Middle East, (Boulder, Colo.: Westview Press).

Sojamo, S., M. Keulertz, J. Warner and J.A. Allan (2012) 'Virtual Water Hegemony: The Role of Agribusiness in Global Water Governance', Water International, 37, 169-182, DOI: $10.1080 / 02508060.2012 .662734$.

Sowers, J., A. Vengosh and E. Weinthal (2011). 'Climate Change, Water Resources, and the Politics of Adaptation in the Middle East and North Africa', Climatic Change, 104, 599-627, DOI: 10.1007/s10584-010-9835-4.

Springborg, R. (2012) 'Egypt: Attempting to Improve "Quality of Administration" without Increasing "Public Accountability"'. In: Kadhim, A. (ed.) Governance in the Middle East and North Africa: A Handbook (London; New York: Routledge).

The Guardian (2014) 'Iranians Brace for Price Hikes as Government Rolls Back on Subsidies'. The Guardian, 28 April, http://www.theguardian.com/world/iran-blog/2014/ apr/28/iranians-price-hikes-government-subsidies (accessed on 19 February 2015).

United Nations (2014) United Nations Indicators, https://data.un.org/ (accessed on 17 March 2016).

USDA (2014a) Food Expenditures by Families and Individuals as a Share of Disposable Personal Income (Washington D.C.: USDA) http://www.ers.usda.gov/data-products/ food-expenditures.aspx (accessed on 19 February 2015).

USDA (2014b) Foreign Agricultural Service Database. Production, Supply and Distribution (PSD). (Washington D.C.: USDA) http://www.fas.usda.gov/psdonline/psdQuery. aspx (accessed on 23 May 2014).

USDA (2014c) Turkey: 2014 Food Processig Ingredients Report, GAIN Report TR4053 (Washington D.C.: USDA) http://gain.fas.usda.gov/Recent GAIN Publications/Food Processing Ingredients_Ankara_Turkey_12-5-2014.pdf (accessed on 17 March 2016).

Verme, P., B. Milanovic, S. Al-Shawarby, S. El Tawila, M. Gadallah and E.a.A. El-Majeed (2014) Inside Inequality in the Arab Republic of Egypt. Facts and Perceptions across People, Time, and Space (Washington D.C.: World Bank).

Voss, K.A., J.S. Famiglietti, M. Lo, C. De Linage, M. Rodell and S.C. Swenson (2013). 'Groundwater Depletion in the Middle East from Grace with Implications for Transboundary Water Management in the Tigris-Euphrates-Western Iran Region', Water Resources Research, 49, 904-914.

Waterbury, J. (1983) The Egypt of Nasser and Sadat: The Political Economy of Two Regime, (Princeton, N.J.: Princeton University Press).

Woertz, E. (2013a) 'The Governance of Gulf Agro-Investments', Globalizations, 10, 87-104, DOI: 10.1080/14747731.2013.760932. 
Woertz, E. (2013b) Oil for Food. The Global Food Crisis and the Middle East (Oxford; New York: Oxford University Press).

Woertz, E. (2014). 'Environment, Food Security and Conflict Narratives in the Middle East', Global Environment, 17, 490-516, DOI:10.3197/ge.2014.070209.

World Bank (2006) Middle East and North Africa. Economic Developments and Prospects 20o6: Financial Markets in a New Age of Oil (Washington D.C.: World Bank).http:// siteresources.worldbank.org/INTMENA/Resources/MainReport.pdf (accessed on 17 March 2016).

World Bank (2014) World Bank Indicators (Washington D.C.: World Bank) http://data .worldbank.org/indicator/NV.AGR.TOTL.ZS/countries?display=default, (accessed on 30 September 2014).

Zurayk, R. (2011) Food, Farming and Freedom. Sowing the Arab Spring, (Charlottesville, Virginia: Just World Books). 